\title{
Great and old earthquakes against great and old paradigms - paradoxes, historical roots, alternative answers
}

\author{
G. Scalera \\ INGV - Istituto Nazionale di Geofisica e Vulcanologia, Via di Vigna Murata 605, 00143 Roma, Italy
}

Received: 13 June 2007 - Revised: 19 October 2007 - Accepted: 19 October 2007 - Published: 2 January 2008

\begin{abstract}
The similarity of the vertical displacements shown by case-history extreme-magnitude earthquakes are scrutinised (Chile 1960, Alaska 1964, Sumatra 2004, ...). A common interpretation - an uprising of lithospheric material can be found, which is supported by the irregularities of the hypocentres distribution along the Wadati-Benioff zones. In the case of major South American earthquakes, a volcanic eruptions-earthquakes correlation is recognisable.
\end{abstract}

Further support to this interpretation is the displacement of the Earth's instantaneous rotation pole $-\approx 3.0$ mas $(\approx 10 \mathrm{~cm})$, observed at ASI of Matera, Italy - the seismic data (USGS) in the two days following the main shock, the geomorphologic data, and the satellite data of uplift/subsidence of the coasts (IGG) make possible a new interpretation of the Great Sumatran earthquake (26 December 2004) based on the second conjugate - nearly vertical - CMT fault plane solution.

All this converges toward different causes of seismogenetic processes, strongly supporting a deep origin of disturbances, fluxes of materials leading to more or less sudden movements of masses, and phase changes, which lead to either earthquakes or silent-slow events in Wadati-Benioff zones. A reinterpretation of the geodynamics of the active margins and mountain building is proposed with a heuristic model that does not resort to large-scale subduction, but only to isostatic uplift of deep material intruding between two decoupling plates in a tensional environment. Concomitant phase changes toward less-packed lattice and buoyancy effect caused by the Clapeyron slope can help the extrusion of material over the m.s.l., constituting an orogenic process. The phenomena expected to occur in the model directly and harmoniously contribute to the building up of the surface geophysical and geomorphological features of the orogenic zones.

Correspondence to: G. Scalera

(scalera@ingv.it)

\section{Introduction}

The great earthquake of Sumatra (26 December 2004; $M=9.3$ ) occurred when many new technological facilities were available in many fields. Especially useful are the data coming from new generations of artificial satellites in defining gravity, magnetism, topography, polhody and their anomalies and variations. Coral reef studies provide additional constraints to topographic changes and analogical and finite-difference modelling help in understanding fault ruptures, wave propagation, tsunamis generation and propagation. But we still suffer from incompleteness of seismic networks in the circumpacific and Sunda-Indochina belts where extreme-magnitude earthquakes occur. Aftershock distributions, which are so important in defining real structure movements, have been detected only for short time windows by temporary land or ocean-bottom seismometer (OBS) networks on segments of the Sunda arc. Because these patterns of hypocenters do not completely fulfil the expectations of the subduction concept, longer or permanent observation times are needed.

The extreme magnitude shallow earthquakes are rare occasions to obtain more precise information and clues about the processes involved. This is because the shallow depth makes the signals - that could drop under the thresholds of instrumental noise if produced by deep earthquakes - stronger and more easily detectable. I will try to show that there are already sufficient clues for more then a suspicion that subduction is not involved in active margin shallow earthquakes, and that it is possible to envisage non-subductive models of evolution of non-collisional orogens. An international scientific institutional effort to install and permanently maintain OBSs and other geophysical instrumentation along the active margins prone to extreme geophysical events should be considered. It is shown that the South American Pacific margin is - because of the occurrence of a number of extreme magnitude earthquakes in the last two centuries $(1835,1868,1906$,

Published by Copernicus Publications on behalf of the European Geosciences Union. 
Table 1. The ten largest earthquakes since 1900.

\begin{tabular}{rllc}
\hline \multicolumn{2}{l}{ Location } & Date & Magnitude $\left(M_{w}\right)$ \\
\hline 1. & Chile & 22 May 1960 & 9.5 \\
2. & Prince William Sound, Alaska & 28 March 1964 & 9.2 \\
3. & Andreanof Islands, Aleutian Islands & 9 March 1957 & 9.1 \\
4. & Kamchatka & 4 November 1952 & 9.0 \\
5. & Off western coast of Sumatra, Indonesia & 26 December 2004 & 9.0 \\
6. & Off the coast of Ecuador & 31 January 1906 & 8.8 \\
7. & Rat Islands, Aleutian Islands & 4 February 1965 & 8.7 \\
8. & Northern Sumatra, Indonesia & 28 March 2005 & 8.7 \\
9. & India-China border & 15 August 1950 & 8.6 \\
10. & Kamchatka & 3 February 1923 & 8.5 \\
\hline
\end{tabular}

Source: National Earthquake Information Center, U.S. Geological Survey.

1960) with a mean return time of 40-50 years, and because of a peculiar correlation between seismic and volcanic phenomena - the key region to be studied in hopes of achieving new, deeper knowledge of natural phenomena.

\section{Case-history major earthquakes - characteristics and analogies}

Highlighting the analogies among the largest historical earthquakes can help in better understanding the real processes at the seismic source. The greatest moment magnitude $\left(M_{w}\right)$ seismic events of the past century are listed in Table 1.

The events that happened in an era of evolution in instrumentation close to the modern one are all the earthquakes after the fiftieth: nrs. 1, 2, and 7 (nr. 8 should be considered an aftershock of the 26 December 2004 quake). The first two were extensively studied and a vast literature exists.

In the occasion of the great earthquake of Alaska (27 March 1964; $61.0^{\circ} \mathrm{N}, 147.7^{\circ} \mathrm{W}$ ) the first available map (Anonymous, 1964) of the uplifted and subsided zones was drawn (see Fig. 10b in Scalera, 2007b). In this map, a long inner belt - at least $500 \mathrm{~km}$ - of subsided crust extended from near Anchorage to Kodiak Island. The subsidence was up to $2.0 \mathrm{~m}$. Uplift with a peak of $8.0 \mathrm{~m}$ occurred on an external emergence belt facing the Pacific (Anonymous, 1964; Landen, 1964; Plafker, 1965).

The focal mechanism gave rise to discussions about the true fault solution - the main or the conjugate (Press and Jackson, 1964; Savage and Hastie, 1966; Stauder and Bollinger, 1966). The first focal mechanism determination by Press and Jackson (1964) was a vertical blind fault of $200 \times 800 \mathrm{~km}$ at $15-20 \mathrm{~km}$ in depth. These discussions without a definite conclusion - preceded the advent of plate tectonics by a few years. The vertical movements detected on the surface (see Fig. 10b in Scalera, 2007b) can arouse suspicion of deep anelastic displacements of visco-plastic material (Scalera, 2007b).
The same clues of anelastic displacement came from the great Chilean earthquake of 1960 (19:10:40 UT on 22 May; $38.05^{\circ} \mathrm{S}-72.34^{\circ} \mathrm{W}$, depth $35 \mathrm{~km}$ ) (Plafker and Savage, 1970; Cifuentes, 1989; Cifuentes and Silver, 1989). A sequence of foreshocks began $33 \mathrm{~h}$ before the main shock (USGS, 2007), rupturing $150 \mathrm{~km}$ of the northern segment of the fault. The records suggest the occurrence of a large slow and silent foreshock on the deepest portion of the fault $15 \mathrm{~min}$ before the main shock, with a seismic moment comparable to that of the main event (Plafker and Savage, 1970; Kanamori and Cipar, 1974; Lund, 1982; Cifuentes, 1989; Cifuentes and Silver, 1989). Lund (1982) hypothesized a solitary wave (soliton) - detected on the strainmeter at Pasadena - generated by the foreshock of $7.9 M_{w}$ which occurred 15 minutes before the mainshock. The observed surface deformation a long internal subsidence zone flanked to an external uplifted one (see Fig. 10a in Scalera, 2007b) - was similar to the great Alaskan earthquake one. Different seismic source models were proposed (Linde and Silver, 1989; Barrientos and Ward, 1990) but some severe mechanical problems remain unsolved (Scalera, 2007b) in a pure elastic view.

Not different is the situation in the case of the great earthquake of Sumatra of 26 December 2004 (Lat $=3.3^{\circ} \mathrm{N}$, Lon $=95.8^{\circ} \mathrm{E}, \mathrm{H}=10 \mathrm{~km}, \mathrm{TU}=26$ December 2004-00h $58 \mathrm{~m}$, $\left.M_{w}=9.3\right)$. Indeed, difficulties arise from the necessity, in plate tectonics, for too long subhorizontal faulting, which strongly conflicts with a coseismic displacement of nearly 3.0 milliarcseconds $(1.0 \mathrm{mas} \approx 3.0 \mathrm{~cm})$ of the instantaneous rotation axis of Earth (Giuseppe Bianco, 2005; Scalera, 2005a, 2007). The polhody path anomaly was disregarded by most people as ascribable to causes unrelated to the seismic event (Gambis, 2005; MacMillan, 2005; Lambert et al., 2006). On the contrary, this anomaly (Kuhn, 1962) should be considered very important because it points to the inadequacy of the pure elastic rebound model.

The Indian Geological Survey, installed a more than 500 km-long digital seismometers network on the AndamanNicobar islands (Mishra et al., 2007), detecting aftershock 
distributions in two different segments of the AndamanNicobar-Sumatra arc. The collected hypocentres need a careful relocation because of the presence of Pn phases and consequent poor depth constraints, but a long nearly vertical "wall" of hypocenters is discernible along all the segment of the arc, which is at odds with the expected pattern. More to the south, near the Aceh Basin, west of North Sumatra, several associated Japanese Scientific Institutions installed a network of ocean-bottom seismometers (OBS) (Araki et al., 2006), which worked for twenty days, providing a precise set of hypocentral data. The revealed pattern of foci seems steeper ( $20^{\circ}$ instead of the $8^{\circ}$ of the Harvard CMT solution) and divided in several segments not defining either a unique or a subhorizontal slip surface. A disruption of a plate margin can be recognized. The surface vertical displacements have patterns analogous to the Alaskan and Chilean events, with the typical coupled belts of external uplifted belts and internal subsided ones (see Fig. 7 in Scalera, 2007b). Only vertical and largely anelastic processes in a non-double couple view can account for the observed phenomena, adopting the second conjugate fault solution (see a more complete discussion in Scalera, 2005b, 2007b). Moreover, the GRACE satellite gravity data, cannot fit dislocation models without substantial lateral and vertical expansion of the oceanic crust being added to the models (Han et al., 2006). This supports the class of models with vertical emergence in a distensional environment (Scalera, 2007a).

Also a littler magnitude - but still "subduction-related" - crustal earthquake like the Chi-Chi, Taiwan, event (21 September $1999 ; 23.85^{\circ} \mathrm{N}, 120.81^{\circ} \mathrm{E}$, depth $=7.0-10.0 \mathrm{~km}$; $M_{w}=7.6$; not listed in Table 1) provides clues at odd with a subhorizontal subduction (Abrahamson et al., 1999; Shin et al., 1999; Cattin et al., 2004). The event ruptured $85 \mathrm{~km}$ of the N-S Chelungpu Thrust Fault. The subductive interpretation has been judged problematic because, albeit a subduction event involving a sub-horizontal fault is envisaged, the surface deformation (Lin et al., 2001; Johnson and Segall, 2004) was steeper than expected (Seno, 2000; Seno et al., 2000). A propagation of the rupture was hypothesized along a sub-horizontal decollement, but the western edge of the fault became progressively steeper up to its final vertical surface emersion, and the hypocenters distribution of the aftershocks sequence (Kao and Chen, 2000; Johnson and Segall, 2004) presents at least three groups of hypocenters. The deeper group (depth $25-37 \mathrm{~km}$ ) bears witness to the plutonic origin of the mass movement. On the western side of the orogen, the Pliocene and Miocene strata $(1.8-23.8 \mathrm{Ma})$ are mutually correctly located, but the Oligocene facies (23.8$33.7 \mathrm{Ma}$ ) - the more central axes of the Taiwan orogen - are unconformably superimposed on the younger layers (Fig. 1c in Johnson and Segall, 2004). This inverted pattern can be the result of the uplift of the orogen core followed or accompanied by a lateral spreading or pushing by extruded mantle material, and thrusting on the younger low-land. Lateral spreading are well documented by geologic and geodetic sur- veys on young orogens (Coltorti and Ollier, 2000; Ollier and Pain, 2000; Ollier, 2002, 2003; Saroli et al., 2005; Serpelloni et al., 2006).

Finally, looking at historical Italian earthquakes, which occurred on the active Calabrian arc (South Tyrrhenian Sea), additional clues of the action of earthquakes in contributing, as part of a long causal chain, to mountain building and spreading of orogens can be recognized. Detailed studies of the great 1638 Calabrian earthquake, of the 1783 great Calabrian seismic sequence (nearly $100 \mathrm{~km}$ of epicentres migration) and of the earthquake of 1905 (INGVCatalogue of the Strong Italian Earthquakes, Boschi et al., 2000; http://storing.ingv.it/cft/; Valensise and Pantosti, 1992, 2006; Moretti and Guerra, 1997; Galli and Bosi, 2003; Cucci, 2004; Saroli et al., 2005; Cucci and Tertulliani, 2006; Tiberti et al., 2006) point to vertical slip along vertical faults and to surfaceward displacement of mantle materials that contribute to the building of the arc, with moments of sudden but limited uplift, creation of marine terraces, all probably caused by transitions from metastable phases to stable open-packed lattice configurations (further details in Scalera, 2007b).

\section{Correlations between earthquakes and volcanic phe- nomena}

The history of correlations between earthquakes and volcanic phenomena on the South American Cordillera (Fig. 1) can be traced further back in time. Descriptions of them can also be found in seventeenth-century European books (D'Avity, 1643; Placet, 1666:74-78 of first edition; see the translation of these pages in Scalera, 2007b). Charles Darwin noted (1897) during his trip along the coasts of South America that the movement of uplift and subsidence of the coastlines is very complicated, and sometime linked with volcanic and seismic events. The association of volcanic phenomena with strong earthquakes was documented by Charles Darwin (1809-1882) on the occasion of the 1835 Concepcion earthquake (Darwin, 1840; Darwin, 1897:236).

Indeed, within a few months of the 1960 Chile earthquake, 17 of 38 active Andean volcanoes (Casertano, 1963) had eruptions or other minor volcanic activities. The following erupted in close coincidence with the seismic event: Copahue, Llaima, Villarrica, Cordon, Calbuco, Lautaro. There were also eruptions of volcanoes to the north: PlanchonPeteroa, San José, Tupungatito, Lascar, San Pedro, Guallatiri (Casertano, 1963; Smithsonian Institution, 2007) (Table 2, Fig. 1d). Similar correlations occurred along all the Cordillera on the occasion of the February 1906 Ecuador earthquake $\left(M_{w}=8.8\right)$ followed by the August Chilean event $(M=8.4)$, including eruptions of Puracé and Reventador in the north, Ubinas in the central section and Cerro Azul, Nevados, Villarrica, Calbuco, Huequi in the south (Smithsonian Institution, 2007) (Fig. 1c). 
Table 2. The data 1800-1999 extracted from the Smithsonian Institution Catalogue of the eruptions for the South American region.

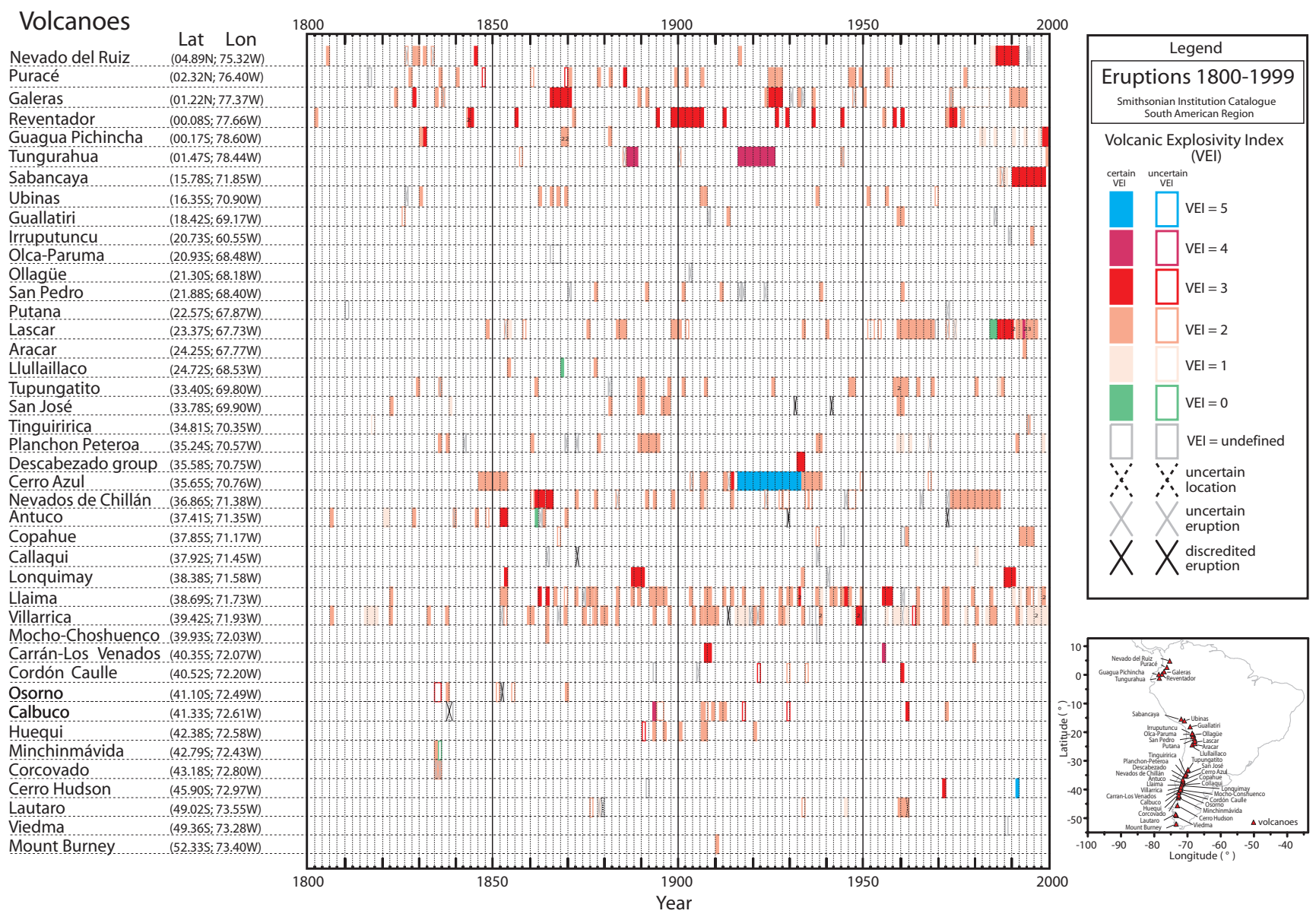

In Table 2 the data from the Smithsonian Institution Catalogue are shown for South American eruptions from 1800 to 1999. In Table 2, all the catalogue data in the time window are made explicit along the time axis, adopting different symbols and colours for different degrees of volcanic VEI (Volcanic Explosivity Index; Newhall and Self, 1982; Simkin and Siebert, 1994). Volcanoes are ordered following their latitude. In the right-lower corner all the volcanoes present in Table 2 are shown in their geographical position. Simple visual inspection of the overall pattern of Table 2 does not immediately suggest the existence of clusters of eruption along the time. Only the more frequent and sometimes continuative activity of a number of volcanoes can be evident (e.g. Puracè, Galeras, Reventador in the North; Lascar, in the center; Nevado de Chillan, Llaima, Villarrica, in the South) along the latitude.

Time clustering appears by purely counting the eruptions yearly and by triennium for all the listed volcanoes. The criterion adopted in counting has been to discard only the discredited eruptions (marked with a grey St. Andrew's Cross in Table 2), accepting the uncertain ones (Fig. 2a). If a volcano has erupted more than once in a year, all the events have been counted (in Table 2 a number indicates how many eruptions have occurred in the year cell). No corrections or weight factors have been adopted for the different degrees of VEI, because of the present impossibility of formulating realistic and general hypotheses on the role of regional geology and geodynamics on the onset and intensity of an eruption. Some spikes of eruptions emerge above the normal "background noise" of eruptions (Fig. 2a). A checking of the real existence of the time-clusters has been performed by recounting the annual and triennial number of eruptions, discarding the uncertain ones in addition to the discredited events. The results are plotted in Fig. 2b, showing that the peaks are not erased by more conservative criteria. The attenuation is more effective on the more incomplete sector of the catalogue, namely the first half of the nineteenth century.

The possible correlation between extreme magnitude earthquakes and eruptions is searched for by plotting as arrows in Fig. $2 a$ and $b$ the time of occurrence of the great South American earthquakes with a magnitude greater than or equal to 8.0. Most eruption-cluster peaks occurred on the occasion of a major seismic event of magnitude $M \geq 8.4$., but a cluster of eruptions is also recognizable in coincidence with 

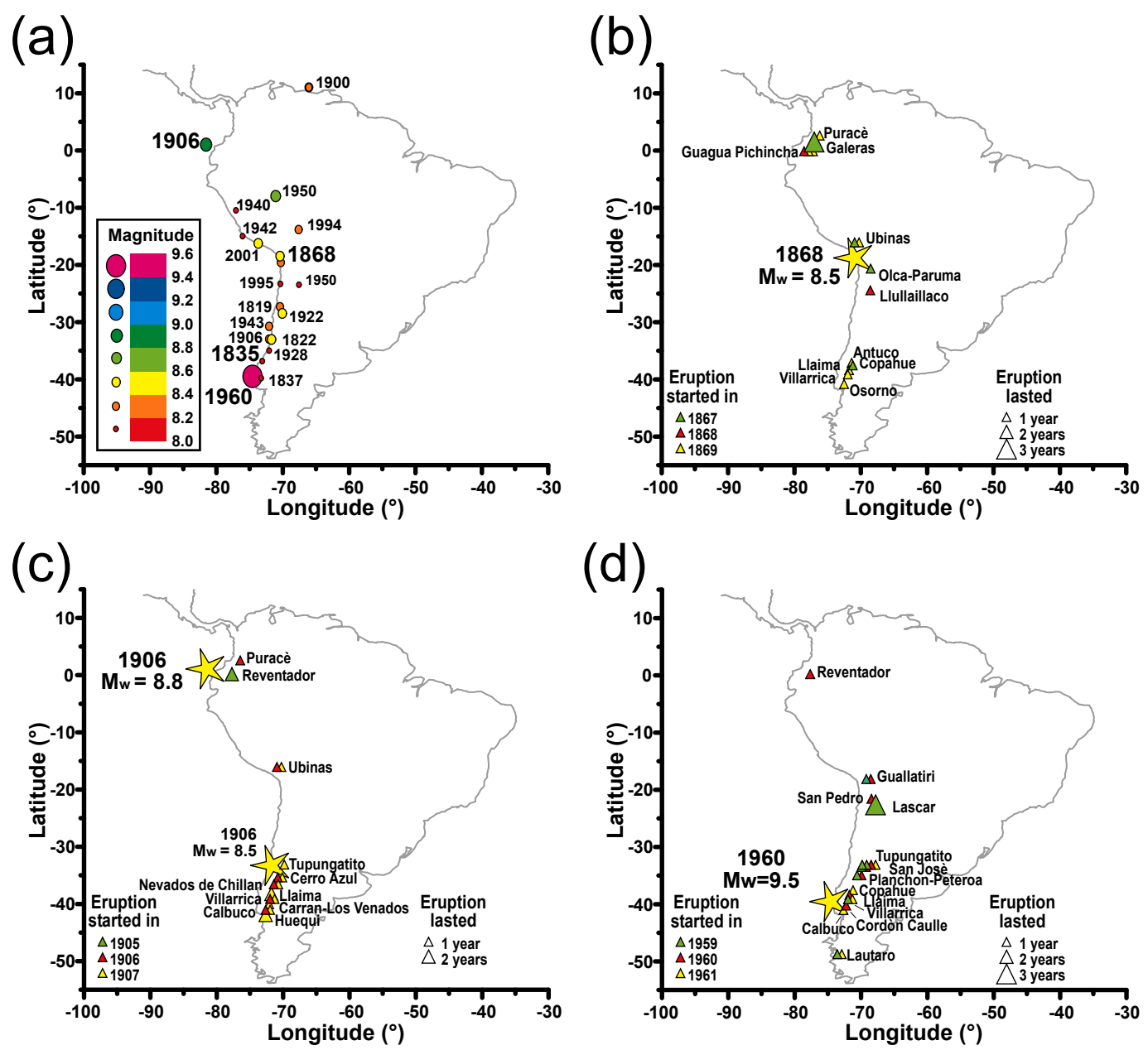

Fig. 1. (a) Main earthquakes that occurred along the South American Pacific margin $(M \geq 8.0)$. (b) The epicentre of the 1868 earthquake and the volcanoes that have erupted in the triennium 1867-1869. (c) The epicentres of the two major earthquakes of 1906 and the eruptions that occurred in the triennium 1905-1907. (d) The eruptions of the triennium 1959-1961, and the epicentre of the Great Chilean earthquake of 1960. Further support to a possible link between major seismic events and volcanic eruption in South America can be extracted from Figs. 2 and 3.

the Concepcion earthquake of 1835 - the correlation already noted by Charles Darwin (1840, 1897:236). The correlation of the 1835 seismic event with eruptions cannot be confirmed by the elimination of the uncertain eruptions (Fig. 2a, b) because the peak disappears in the background eruptive activity. This means that great attention must be devoted to various possible causes of both incompleteness and overcompleteness of the catalogue. Causes of incompleteness can be the lack in historical time of a network of volcanologic Observatories, and, in more recent times, the occurrence of weakness in - and reduced frequency of - scientific field data collection during the two world wars. On the contrary, the occurrence of extreme intensity seismic events can lead to a sort of compulsion to search for news about concomitant eruptions. This can produce a rise in recognized eruptions above the normally noticed ones, and the inclusion in the correlation of eruptions that had already started several years before the earthquake - with no relation to it.
In addition, possible errors in reporting the news in the local chronicles and newspapers can lead to the attribution of the same eruption to two or more volcanic apparatuses, with further increase of the over-completeness effect. This misleading phenomenon has certainly become less and less important since the second half of the twentieth century. The last two decades of the twentieth century, with more careful and improved systems of data collection, show a progressive increase in the rate of eruptions per year (e/y), which reach a value higher than $5 \mathrm{e} / \mathrm{y}$. Whether this rate of "background noise" remains constant or not, and whether the increased noise makes possible the recognition of the peaks of eruption correlated to major earthquakes in the present century, too, is an open problem that will be resolved by future catalogue data. However, the presence of the strong peak linked to the 1868 earthquake $(M s=8.5)$, preceded by a decade of apparent intense volcanic activity is a clue to the real existence of the correlations. 

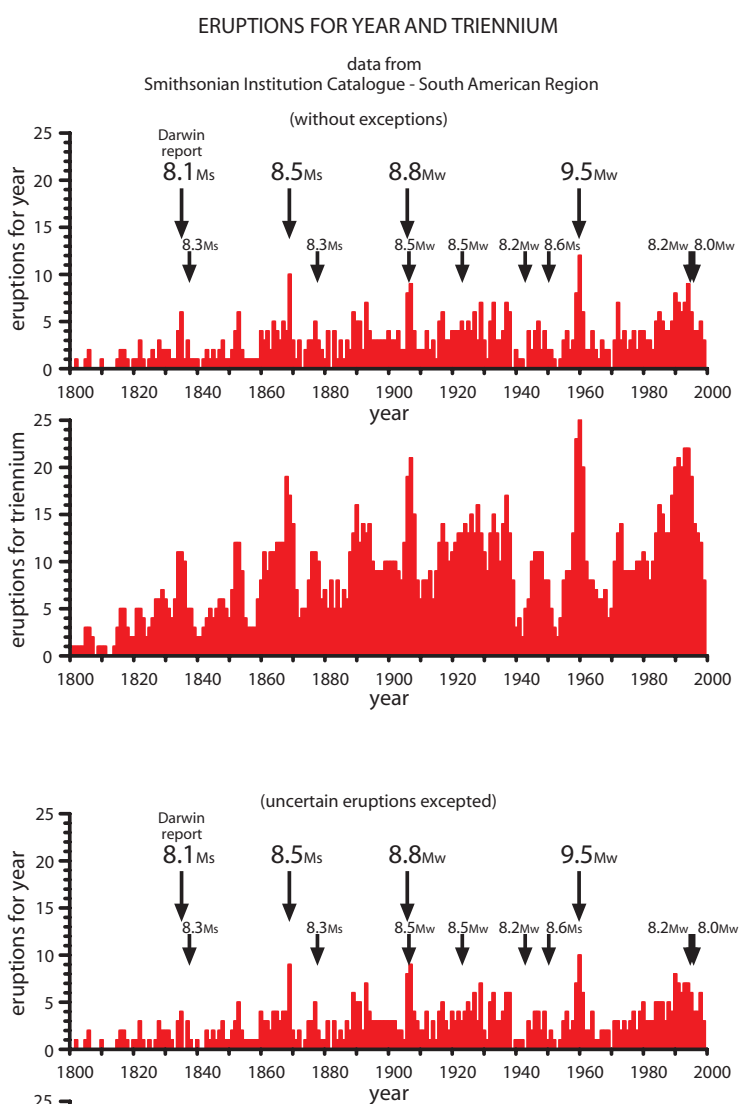

(b)

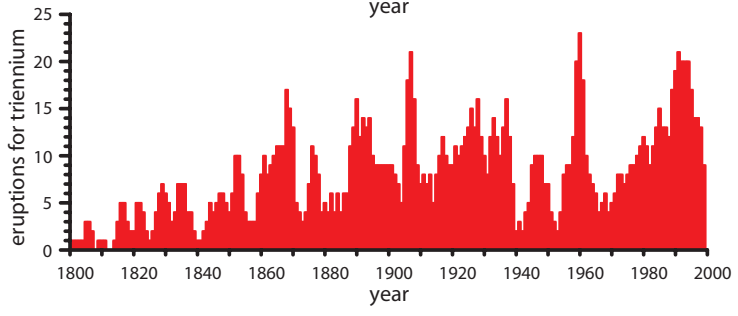

Fig. 2. The data from 1800 to 1999 of the Smithsonian Institution catalogue of eruptions for the South American Region have been used to plot the annual and triennial number of eruptions along the time axis. In (a) all the non-discredited data have been used. In (b) the uncertain eruptions have been omitted. The cusps of eruptions coinciding with the occurrence of great-magnitude earthquakes are clear in both cases. In the time zone of greater incompleteness of the catalogue - the beginning of the 19th century - only the peak of eruptions associated to the Concepcion event of 1835 becomes indiscernible passing from (a) to (b). The low rate of eruptions around 1940 could be due to incomplete observations caused by the 2 nd World War, but the occurrence of similar low-rate periods around 1953 and 1968 is unexplained. Long periods of higher volcanic activity - e.g. 1920-1938, 1980-2000 - are also present. At the moment no explanation for this fluctuations exists nor it is possible to envisage links with the occurrence of very deep and strong seismic event like the 1994 Bolivia one $(M=8.2$; depth $=641 \mathrm{~km}$, data USGS, 2007). The same association of major seismic events and increased rate of eruptions cannot be recognized in other WadatiBenioff zones.
In Fig. 3 the eruptions-occurrence details of the four years before and after the great earthquakes of 1960, 1906 and 1868 are shown. The eruptions with unknown starting dates are arbitrarily ascribed to June. The 1868 event and the 1906 events ( $M=8.8$, Equador, followed by a $M=8.4$, Chile) are associated with a more time limited cluster of eruptions - lasting two year - than the 1960 one - lasting three years. While it is impossible to envisage a precise cause-effect link, however, the data suggest a possible connection between WadatiBenioff zone earthquakes and volcanic phenomena, with a common cause due to a movement - possibly surfaceward of deep mantle material (Scalera, 1997, 2006b, c, 2007b).

\section{Non regular distribution of hypocentres on the Wadati-Benioff zone}

Further clues of a possible different origin of the disturbances that originate earthquakes on the Wadati-Benioff zones (WBZ hereafter) is the pattern of hypocentres distribution, if observed on a larger scale. In Fig. 4 the entire WBZ from Equador to Tierra del Fuego is plotted, revealing a cluster structure of the pattern (data from the Catalogue of the Relocated Hypocenters, by Engdahl et al. (1998)). These clusters or filaments have the tendency to taper as they go deeper and can be considered real characteristics, because their separation can easily reach several degrees. They suggest the idea of a narrow and deep origin of the disturbance, which propagates and becomes progressively wider toward the surface. If the clusters are taken as basic features in constructing new interpretations of WBZ, there is little room for a downgoing slab. It seems more credible that an upward migration of matter or energy could be involved. The volcanic provinces (black circles in Fig. 4 represent volcanoes that erupted in historical time) are roughly divided in relation to the seismofocal zone features. Some NorthSouth gaps in the intermediate-depth hypocentral pattern $(100 \mathrm{~km} \leq$ depth $\leq 300 \mathrm{~km})$ are in relation to gaps and lower density of the volcano distribution, adding further proof on behalf of the possible stronger-than-supposed link between seismic and volcanic phenomena (Scalera, 1997). Geomorphic and tectonic field studies of the Andes point toward a rapid uplift of the Cordillera from Miocene, and the creation of the Interandean Depression as result of a lateral spreading (Coltorti and Ollier, 2000), which is at odds with a compressional origin of the orogen. Very problematic - in a region in which subduction is credited with being in steady-state activity at least since the Cretaceous - is the young age of the uplifting and the tectonic stand-still that enabled a recognized planation phase of the Cordillera (Coltorti and Ollier, 2000). A different source of energy for mountain building should then be searched for, in agreement with the requirements of the orogenic model proposed in a following section of this paper. 


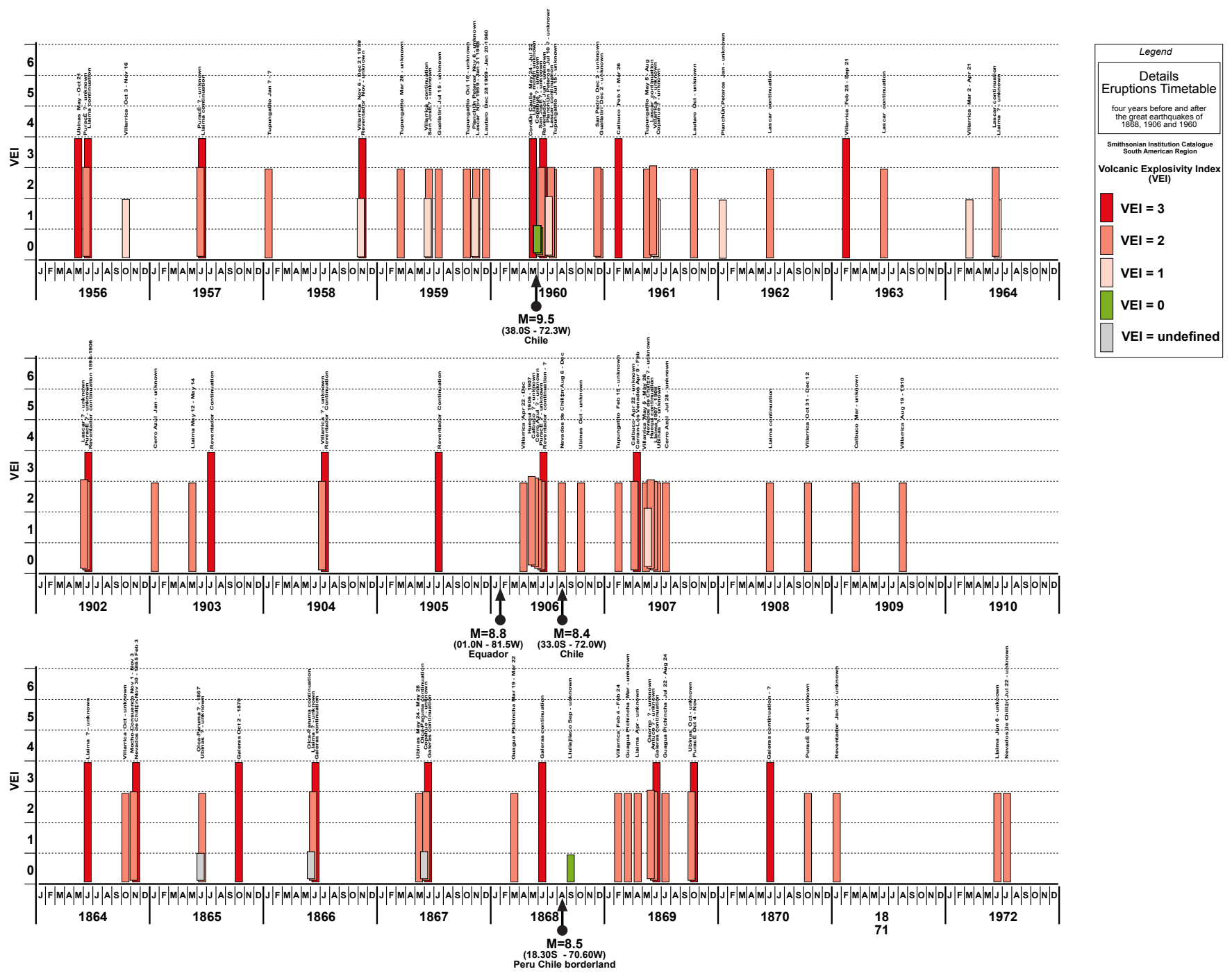

Fig. 3. Details of the eruptions that occurred four years before and after the major South American earthquakes. The VEI is represented both in colour and in length on the vertical axis. The details of the eruptions are shown for the 1868, 1906 and 1960 seismic events. The eruptions are identified by the name of the volcano and - if available - the starting and ending dates. If, in the Smithsonian Institution Catalogue, the month of the starting date in not available, the bar representing the eruption is assigned arbitrarily to June of the same year. While the occurrence of a greater rate of eruptions on the occasion of major earthquakes is undeniable in this plot, it is impossible today - mainly because of a frequent lacks of starting months - to resolve the problem of what phenomenon is the cause of the other. A supplemental long time lapse for collecting data is needed to achieve more solid deductions. A common cause of both eruptions and earthquakes - such as surfaceward movements of the mantle that could be caused by phase changes and associated phenomena - is another possibility and it is the preferred hypothesis in this paper.

Further example is the Sunda arc, which in its segment from Sumatra to the Andaman islands, has hypocentres no deeper than 250-300 km. Deeper hypocenters are present under Java up to New Guinea, with focal depths up to $700 \mathrm{~km}$. Here the foci cluster in large columnar zones of which the great islands and groups of islands are like (architectonic) capitals (Fig. 5). The north-northeast motion of the Indian plate sea-floor under the Sunda arc (Puspito and Shimazaki, 1995; Hafkenscheid et al., 2001) should produce a similar uniform downward motion of the subducted slab, without preferences for earthquakes occurring under the islands. Then "subduction" is unlikely as a source of this nonuniform columnar hypocentral pattern observed under that boundary.

This is a general situation, and all the WBZs present a filamentous pattern of hypocentres (Scalera, 2006b, c, 2007a, b). Few filaments can be recognized under the sintaxial zones of Himalaya - were the orogen assumes its maximum curvatures - and likewise it occurs under the maximum curvature of the Apennines (Calabrian arc, south Tyrrhenian sea) and 

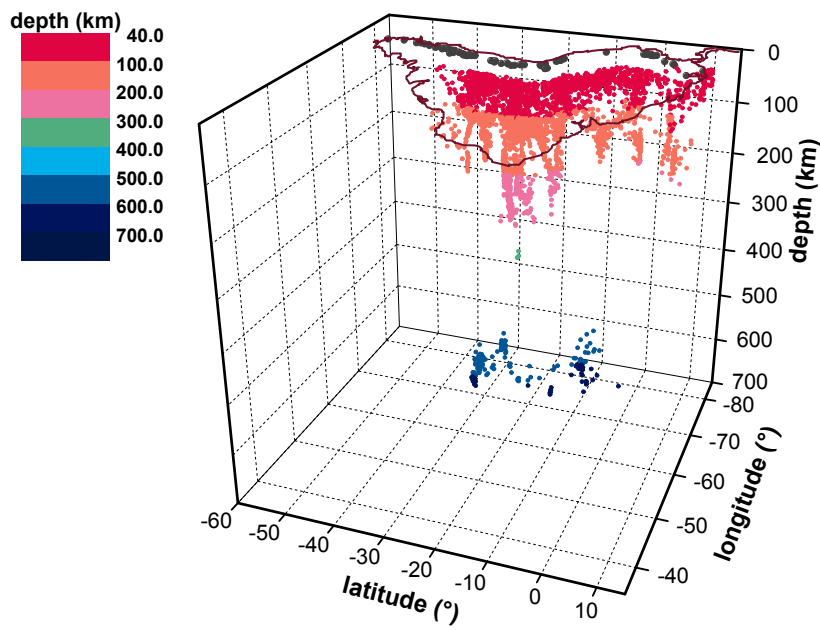

Fig. 4. A 3-D plot of the entire Wadati-Benioff zone beneath South American Pacific margin. Planar distributions of hypocentres cannot be recognized. Clusters of hypocentres tapering downward are the typical patterns. The earthquake data (depth $\geq 40 \mathrm{~km}$ ) have been extracted from the Catalogue of the Relocated Hypocentres by Engdahl et al. (1998). The black circles on the surface represent the 72 volcanoes that have erupted in historical time (data from Smithsonian Institution Catalogue). There it is possible to discern a correspondence between zones lacking intermediate depth hypocentres $(100 \mathrm{~km} \leq$ depth $\leq 300 \mathrm{~km})$ and surface zones lacking active volcanoes. This fact suggests a stronger-than-expected link between volcanism and seismicity already pointed out in other tectonic situations (Scalera, 1997).

Carpathians (southern Carpathian arc, Vrancea region, Romania), were single tubular clusters are present extending up to $500 \mathrm{~km}$ and $200 \mathrm{~km}$ respectively (see Fig. 12 in Scalera, 2007b).

Problems and paradoxes could be resolved more naturally by hypothesizing sudden aseismic changes of phase with an increase of volume at a great depth - in a tensional regime - or, if occurring at subcrustal depth, elastic fracture of the overlying brittle material accompanied by a more continuous but sudden anelastic flow (Scalera, 2007b). These "subductions" - that in Calabrian and Vrancea zones are envisaged active along single filaments or narrow ribbons - are producing severe conceptual problems to the currently accepted paradigm, and these difficulties should be considered true anomalies in the Kuhn's sense (Kuhn, 1962), preluding a reorientation of the geoscientist's community.

\section{Is large scale subduction really a necessary concept?}

Recently, well grounded doubts about the real existence of the large scale subduction have been posed from a review of the mantle seismic tomographies published by Fukao et al. (2001). The colder Pacific lithosphere were expected to be detectable up to the core-mantle boundary, but an horizon-
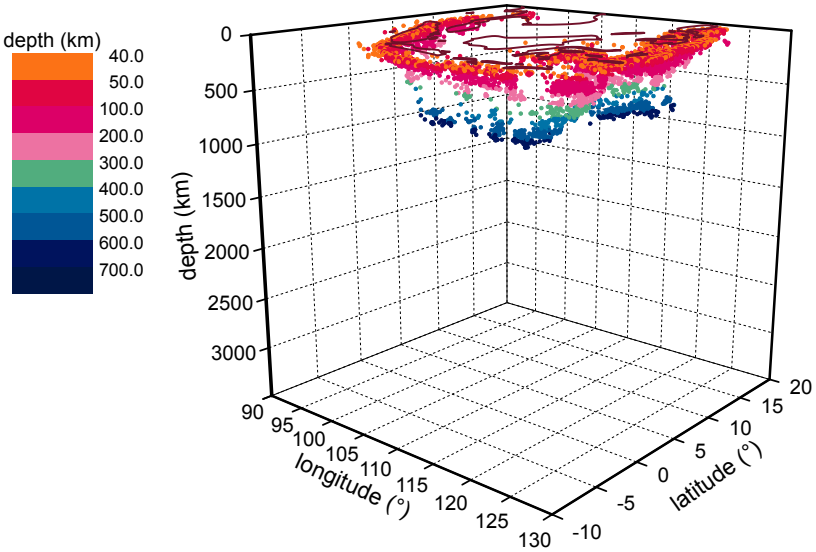

Fig. 5. A further example of three-dimensional large- scale plotting of a Wadati-Benioff zone, with depths greater than or equal to $40 \mathrm{~km}$. The Sunda and Indochina zones are represented. The foci cluster in large columnar zones of which the great islands and groups of islands are like (architectonic) capitals. This is a general characteristic of the Wadati-benioff zones whose hypocentres cluster in filamentous distributions, a fact that is at odds with the expected planar (deep angle around $45^{\circ}$ ) or spoon-like patterns. The data are from the Catalogue of Relocated Hypocentres by Engdahl et al. (1998).

tal bending of the revealed high velocity anomalies along the transition zone has often been detected. Moreover, an eventual tendency of this horizontal anomaly to bend back toward the surface is also discernable. This situation was judged so unexpected and incompatible with the current paradigm that the authors (Fukao et al., 2001) speak of insurmountable mechanical difficulties. A pattern of near vertical high velocity anomalies that meet a vast horizontal anomaly extending in the transition zone of nearly all the Mediterranean region has been similarly detected by Piromallo and Morelli (2003) and Spakman and Wortel (2004). Likewise, the high resolution tomographies imaging up to core mantle boundaries the Americas mantle (Ren et al., 2007) - albeit the authors tries to incorporate their results in the current paradigm - cannot hide the extreme difficulty in interpreting the revealed complex pattern of high velocity anomalies in terms of subduction.

If, in addition, we consider that a great circle can be found on the Earth's globe that crosses only regions in distensional situations (Perin, 1994, 2003), leading to an unavoidable paradox (and to grotesque deformations of the globe if active margins are believed to be compression structures), the conundrum could be resolved by discarding the subduction concept - but maintaining some limited amount of under- and over- thrust - and by searching for a more adequate model describing the active margins geodynamics. 


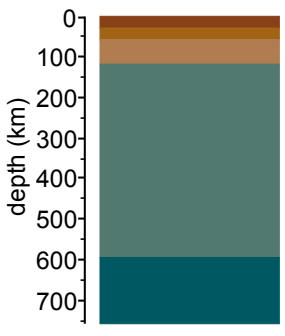

(a)

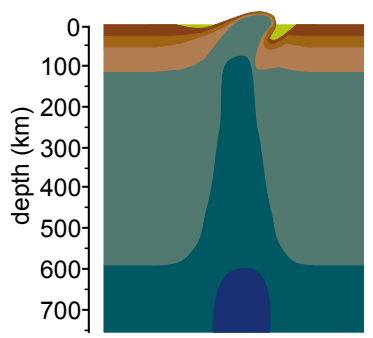

(d)

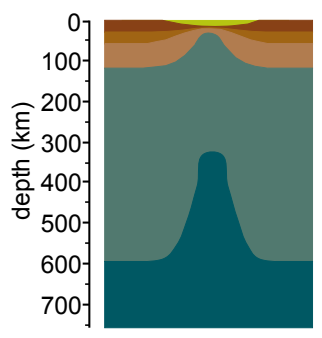

(b)

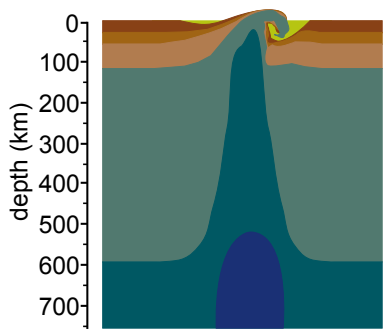

(e)

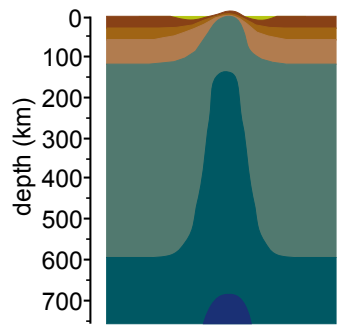

(c)

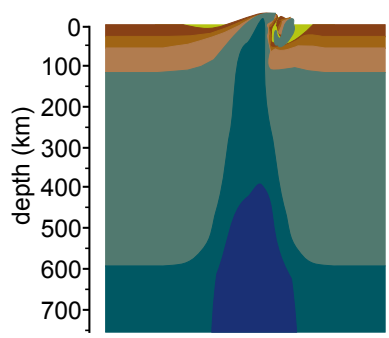

(f)

Fig. 6. The proposed non-collisional model of fold-belts building (in this figure only the flux of the materials is represented, without taking into account the phase transitions, which are represented in Fig. 7, right). Only a mono-vergent situation - like the Apennines - is shown here, but two-vergent situations can be envisaged. Starting from left, a tensional situation produces a stretching of crust, lithosphere, and mantle. Due to the necessity for isostatic compensation (no more than about ten kilometres in depth can be attained on the earth's surface. See e.g. Hilgenberg, 1974) the greater effect of the stretching appears as a strong uplift of the lithospheric and mantle materials. On this uplifting column, an excess of space becomes necessary because the mantle material must undergo phase changes toward more unpacked crystal structures (Green and Ringwood, 1970; Ringwood, 1991). This surplus of increasing volume of the decompressed material is sufficient not only to fill the space between the vertically split lithosphere and mantle, but it can also produce updoming of the crust, and lateral pushing of crustal layers. An effect facilitating the uplift is the downward displacement of the phase transition zones due to the effect of the Clapeyron curve slope (see Fig. 7). Then the created true orogen can undergo erosion, summital collapse and gravitational spreading, with final denudation of metamorphosed crustal material previously buried by gravity nappes, together with several kinds of mantle facies. Different rates of rifting - and evolution of the rates through geological time - can lead to different kinds of orogens from continental to mid-oceanic-ridge ones.

\section{A new model of orogenic evolution}

Considering all the above supporting clues - coming from a number of different fields - a unitary interpretation for the involved phenomena and a new non-collisional interpretation of the orogenic processes and fold belt building is tried, which does not resort to subduction (Fig. 6). The orogen evolution sketch presented here is highly simplified and does not have the pretension of being applicable to all possible tectonic situations. In this initial formulation, the phases of evolution of the orogen described in the model are analogous to the different phases that can be distinguished from south to north on the Apennines and Alps, and on the Himalayas at a more mature stage.

The non-collisional model starts with undisturbed horizontal layers situation from the surface to the lower mantle (Fig. 6a). Tension is subsequently supposed to act and it is envisaged that a stretching of the lithosphere will gradually develop (Fig. 6b). A surface furrow appears (Fig. 6b). The trough increases its depth (no more than ten kilometres of depth can be attained on the earth's surface. See e.g. Hilgen- berg, 1974, for an explanation of the oceanic trenches), the crust grows thin, and induces a symmetrical geometrical change at the lithosphere and upper mantle bottoms, with development of uplifts of materials and displacements of the layer interfaces. In Fig. 6 only the flux of the materials is represented, without taking into account the phase transitions and the layers boundaries, which are represented in Fig. 7. Isostasy makes the inverted troughs at the mantle interfaces and their evolution more pronounced than the surface ones. The depression on the surface can eventually evolve in a sedimentary basin.

An horizontal tensional state and an upward flow of deep materials, without any other associated process, cannot lead to an uplift of the topographic surface and to an orogenic process. However, if the tensional state and the upward movement are associated with phase changes (Green and Ringwood, 1970; Ringwood, 1991) of the rising deep materials toward less-packed lattices, then the net increase of volume can lead to a non uniform-in-time updoming of the topography (Fig. 6c), preparing the slow and complex processes that finally evolve into a fold belt (Fig. 6c, d, e, f). It is possible to 

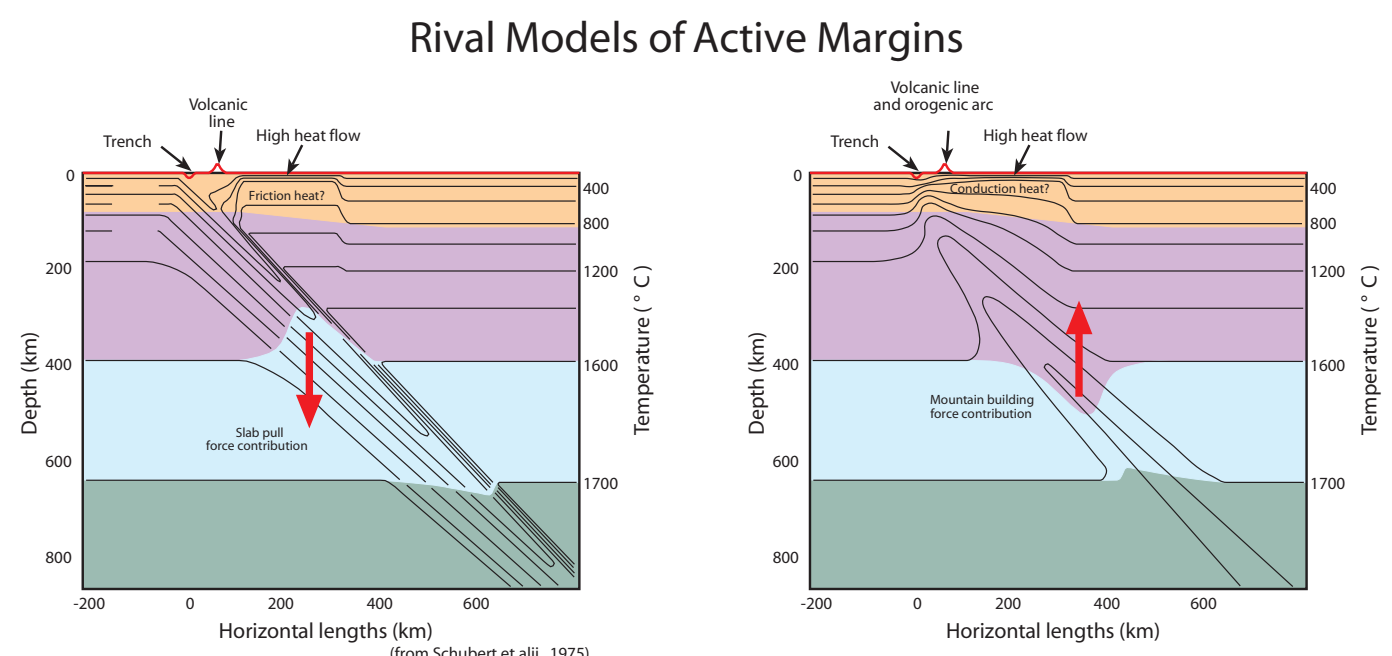

Fig. 7. Two rival models of the active margins. Left: the subduction model is represented with the effect of the downward adiabatic transport of the isotherms. Since, at lower temperatures, the phase transformations occur at lower depths (Clapeyron slope effect), a protuberance of denser material over the $410 \mathrm{~km}$ discontinuity contributes to the so called "slab pull" force (retraced from Ranalli, 1995). Right: the positive anomalies of seismic velocity underneath the trench-arc zones - revealed by tomographic methods - are interpreted as intrusions of isostatically surfaceward transported material. In this case the isotherms are also transported toward the surface thus locally influencing the depth to which the phase transition occurs. This last effect is opposite to the one in the subductive model and a protuberance of lower density material is created in the denser transition zone. The buoyancy of this protuberance, together with the excess of volume involved in phase transitions toward less-packed lattice, contributes to the outpouring and lateral pushing of material on the surface, namely to orogenesis.

speak of phase changes driven by deep isostatic uplift. Initial ideas on the general role of prograde or retrograde mantle phase transformations - in the formation of depressions or uplands - was formulated by Subbotin (1970), and Mouritsen (1975) - in the field of planetology and building of rim structures - expressed an idea of a surfaceward flow of magmatic material, in a distensional environment, which built compressional uplifting structures on the land surface.

A concomitant upward directed force can help to build the orogenic process because of the favourable buoyancy effect coming from the Clapeyron slope of the phase changes at the 410 and $520 \mathrm{~km}$ discontinuities. In the classical plate tectonic view, because the hypothesized "subduction" transports downward cold isotherms, the different slopes of the Clapeyron curve on the P-T diagram of the phase changes produce an uplift of the $410 \mathrm{~km}$ and $520 \mathrm{~km}$ boundaries between olivine and $\beta$-spinel and between $\beta$-spinel and $\gamma$ spinel (Clapeyron slope $>0$ ). The dome of denser material produces the so called slab-pull force (Fig. 7, left). Likewise a depression of the boundary allegedly occurs at the $650 \mathrm{~km}$ boundary between $\gamma$-spinel and perovskite+magnesiowüstite (Clapeyron slope $<0$ ) (Fig. 7, left).

In the model proposed in this paper (Fig. 7, right), instead of a subducting slab, a surfaceward flowing material is considered, and the situation at the upper and lower boundaries of the transition zone is inverted. The $410 \mathrm{~km}$ and $520 \mathrm{~km}$ discontinuities will subside while the $650 \mathrm{~km}$ boundary will be uplifted (Fig. 7, right). The effect is not a negligible one.
Indeed, at $410 \mathrm{~km}$ and $520 \mathrm{~km}$, the upward transport of the isotherms displaces the phase boundaries downwards, creating a depression of lower density material surrounded by a denser one, with a net tendency to buoyancy. A reverse Clapeyron slope at the $700 \mathrm{~km}$ discontinuity produces a contrary directed force, but of lesser magnitude. The total force is then of buoyancy and it is of key importance in building the topographic uplifting and folding.

The extrusion of materials driven both by phase changes (with increasing volume along all the isostatically rising column) and by buoyancy of transformed materials (Fig. 7, right) could cause seismicity (surface, intermediate and deep seismicity) with a pattern of hypocentres distributed along Wadati-Benioff zones. The intermediate and deep (up to $700 \mathrm{~km}$ ) seismicity of the Earth could be explained - following Ritsema (1970) - by the effects of phase transformations (propagation of strain and of instability conditions). In my interpretation, these phase transformations occur along the isostatic uplift path, and not along a downgoing subduction path. The observed filaments or clusters of deep hypocentres are explained by the model through the occurrence of seismically activated zones by irregular and episodic activation of mass and energy transmigration in a laterally nonhomogeneous mantle - in terms of composition, thermal distribution, stress and strain.

The uplift and extrusion of materials - and their occupation of room above sea level - will be the cause of lateral pushing and warping of crustal layers, exposition of the top 
of the doming zone to the action of gravitational spreading and erosion, all phenomena well documented on fold belts (Ollier, 2002, 2003). The lateral pushing of the extruded materials can cooperate with gravity to the creation of the diffusely observed very long sub-horizontal overthrusting (also many tens of kilometres), which have never been explained by gravitational spreading alone (Viti et al., 2006).

The heterogeneous geological and physical conditions around the initial furrow can drive asymmetrical or symmetrical spreading (mono-vergence or bi-vergence) of the excess material, driving the produced nappes to overthrust the sediments of the pre-existing trough and their underlying crust, forcing both of them along a burial path that simulates the subduction process, but without reaching depths greater than 50-70 km (Fig. 6e, f).

At the boundary between uplifting mantle material and down-pushed crust and lithosphere, metamorphism, mixing, migmization, upward transport of fragments of the buried lithosphere, inverted metamorphism etc. can occur (Fig. 6e, f). The exposure on the Earth's surface of the "granite series" (Read, 1957; Pitcher, 1993) and of the HT/HP-UHP metamorphic facies can be explained by the action of the "piston" of the increasing volume phase changes. This action avoids the paradox of the "two way path" (Ernst, 2005) never resolved by plate tectonics.

The densities of the five most common phases at their typical depths are shown in Table 3 (Anderson, 1989, 2005), together with the volume variations passing from each mineralogical phase to the next, and the total volume variation more than $20 \%$ - expected for a complete succession of five phase transitions. If the geofracture detaching the two plates reaches great depths - at least the lithosphere thickness - and arguing that the $\gamma$-spinel $(330 \mathrm{~km})$ is involved in the uprising, then the more than $7 \%$ increase in volume can potentially be sufficient to build an uplift of more than $20 \mathrm{~km}$ in Earth's interior. A greater depth of detachment (such as the one envisaged in Fig. 6) can produce internal uplifts of greater values. The erosion does not permit these high uplifts on the topographic surface and only observable heights of less that $9.0 \mathrm{~km}$ exist today. The values are in agreement with the magnitude order of the uplifts (topographic + eroded) evaluated by geologists on real orogens.

The proposed new interpretation can explain the observed non uniformity in time of the growth of the fold belts. Periods of enhanced growth are linked with a deep mineralogical phase which - involving deep isostatical rising and having reached and exceeded the suitable lesser depth, pressure, temperature, and/or coming into contact with a suitable fluid catalyser - can gradually turn into lighter phases. Also, the widespread phenomenon of uplifted terraces (Darwin, 1840, 1897; Doglioni et al., 1994; Moretti and Guerra, 1997; Cucci, 2004; Galli and Bosi, 2004; Cucci and Tertulliani, 2006; among others) can be related to non-uniform development of the deep phase changes. Obduction of ophiolites is a further process that can find a simple explanation in this framework.
Table 3. Typical mineralogical phases of the mantle and their densities. The transition from a phase to the next shallower one occurs with a variation of volume. The total variation of volume is more than sufficient, extruding over the Earth's surface, to build an orogen.

\begin{tabular}{ccccc}
\hline & Phase and typical depth & Density $\left(\mathrm{g} / \mathrm{c}^{3}\right)$ & $\Delta \mathrm{V} / \mathrm{V}$ & $\Delta \mathrm{V} / \mathrm{V}$ total \\
\hline 1. & $\alpha$-olivine $(85 \mathrm{~km})$ & 3.31 & $4.8 \%$ & \\
2. & $\beta$-spinel $(220 \mathrm{~km})$ & 3.47 & $2.3 \%$ & \\
3. & $\gamma$-spinel $(330 \mathrm{~km})$ & 3.55 & $10.4 \%$ & $22 \%$ \\
4. & Ilmenite $(570 \mathrm{~km})$ & 3.92 & $4.6 \%$ & \\
5. & Perovskite $(710 \mathrm{~km})$ & 4.10 & & \\
\hline
\end{tabular}

The same rate of surface uplift cannot be expected if the rate of rifting of the couple of plates is different, and probably the difference between mid-oceanic ridges (marine orogens) and continental fold belts is maintained by the different rate of rifting of the two plates involved - mid-oceanic ridges having higher rifting rates which does not allow the growing volume to reach and overcome sea level. In this interpretation the mid-oceanic ridges are considered the oceanic version of the continental fold belts, with the difference that the folds and overthrusts are unlikely to occur.

In both cases of this interpretation - low or high rifting rate - the initial phases of the orogenic process provide the forming and evolution of tectonic structures that resemble the geosyncline tectonic framework (Aubouin, 1965). The rate of rifting determines whether the initial narrow trough - e.g. like the Red Sea trough - evolves into a true ocean divided by a mid-oceanic ridge or is filled by sediments and successively undergoes an uplift and folding as in the geosyncline scheme. A region whose rifting rate oscillates around an equilibrium value between the lower ones sufficient to produce dry-land fold belts and the higher ones leading toward oceanic evolution, can develop large emplacements of ophiolitic fields (e.g. Zagros, Oman) and extensive occurrence of salt domes (Stöcklin, 1981, 1989).

The relation between the magma temperature and magma iron content (low T/low Fe; high T/high Fe) could be also well correlated within this model. This can be caused by the surfaceward transport of the isotherms associated with a deeper provenance of the mantle material - from zones richer in this metal (Rohrbach et al., 2007). Some other geochemical properties of the HIMU and EM-1 mantle source incorporated in orogens can be explained by erosion of old continental crust and lithosphere instead of recycling of ancient crust and deep sea sediments (Gasperini et al., 2000; Hanan, 2000), in an interpretation of the Mediterranean as a continuously nascent ocean (Scalera, 2005b). In this slowly expanding Mediterranean the emplacement of basalts has occurred ever in proximity of continental lithosphere. 
The possibility to resolve the paleogeographical paradox of the too limited amount of microcontinent's continental crust stored in the orogens - e.g. the Alps; up to two orders of magnitude of discrepancy (Polino et al., 1990; Stöckhert and Gerya, 2005) - is also among the promises of this noncollisional model, which deserves to be further implemented.

Finally, a second promise to be investigated is the possible relation between the actual neotectonic period (Ollier, 2003) of enhanced orogenic activity (a time lapse from a few million years ago until the Recent) and the minimum of the global spreading rate of the ocean floors (see the maps in Müller et al., 1997; McElhinny and McFadden, 2000; Müller, 2007). The present time of stasis of global expansion could be related to an increased possibility to extrude towards the surface the excess of volume produced by phase changes. Are the older minima in the map related to older orogenic periods?

\section{The HP and UHP petrological phases}

Many efforts have been devoted in the last few decades to explain the presence of high pressure (HP) metamorphism and ultra-high pressure (UHP) metamorphism on continental orogens (see reviews of the field of Platt, 1986; Ernst, 2000, 2001, 2005; Searle et al., 2001; Chopin, 2003; among others). The ascertained facts are that the exhumed UHP assemblies are mostly old continental crust, that the size of these exposed facies is small and sheetlike, and that a rapid decompression (upraise) took place. Alleged evidence of progressively higher depths of provenance of the metamorphosed facies (from $2 \mathrm{Gp}$ to recently reported $6 \mathrm{Gp}$ for microdiamonds; Chopin, 2003) have led the UHP assemblies to be considered and presented as the irrefutable proof of the real existence of subduction, and consequently as the definitive confirmation of the plate tectonics schemata. In my opinion, this is a misunderstanding, both because the burial of crustal and lithospheric material is not synonymous with subduction, and because the alleged great depth of burial can be exaggerated by not considering several possible concomitant processes.

The presence of fluids and gaseous compounds is a source of strong variation in the $\mathrm{P}$ and $\mathrm{T}$ condition of phase changes (Ernst, 2005). CO2 is reputed to favour crystal formation and also to increase the order of magnitude of the viscosity of the material in which it is dissolved. The presence of a deep source and rising of $\mathrm{CO}_{2}$ can be a factor in the generation of deep and intermediate earthquakes. Also, the probable presence of water in the mantle (Lawrence and Wysession, 2006) at considerable depths can be sources of deviation from the normal PT conditions in phase transitions. The existence of the LVZ - depth $60-150 \mathrm{~km}$ - and the revealed seismic anisotropy similarly ascribable to water circulation or trapping under the orogens must be recalled (Babuška et al., 1993; Crampin, 1999; Mainprice et al., 2000; Margheriti et al., 2003).
Although static tectonic overpressure is limited by the typical mechanical strength of rocks $(\approx 1 \mathrm{~kb})$, earthquakes can be additional factors in creation of an impulsive condition of very high stress, which in turn can be the cause of phase transformation of little slice-like portions of materials. Moreover, deviatoric stress has long been recognized as a factor in lowering the depth (and the hydrostatic pressure) needed to produce facies like coesite, blue shists, eclogite and many other HP-assemblies (Carey, 1976). In other words, deviatoric stress is a source of localized overpressure (Stöckhert, 2005). The tectonic environments in which the phase transformations happen - orogenic continental belts and trencharc-backarc active margins - are unquestionably centres of significant deviatoric stress.

Earthquakes are the most important circumstantial evidence for local storing and releasing of deviatoric stress. The possibility that lenses-like HP-UHP exhumed fragments could be mechanical products (an anvil effect; see the key papers of Mancktelow, 1995, 2000; Stöckhert, 2005) of major earthquakes occurrence at depths not exceeding a few tens of kilometres should be considered. The presence of relatively long lasting viscous flows besides the elastic fractures - a process strongly indicated by the extreme magnitude shallow earthquakes (Scalera, 2005a, 2007b) - further supports the possibility of dynamic overpressures.

\section{Conclusions}

A number of clues coming from historical and present time data converge toward the necessity of a reinterpretation both of the so-called subduction zones and of the associated orogenic arcs.

An unavoidable indication of prevailing surfaceward movements of mantle materials comes from analysis of Polar Motion in the case of the major Sumatran "subduction" earthquake (Scalera, 2005b, 2007b). Similar indications come from the correlation between eruptions and major earthquakes recognizable along the Andes region. A common cause of both earthquakes and eruptions can be envisaged in episodic mantle material movements.

The 3-D plots of the hypocentral locations of a number of Wadati-Benioff zones reveal that planar or spoon-like distribution of intermediate and deep hypocenters is not the normal characteristic pattern. The hypocentres spatially distribute on groups of elongated clusters or filaments that taper downward. Also "single filaments" can be recognized as the ones beneath the Strait of Messina (Southern Tyrrhenian Sea) and the Vrancea region (Romania). No subduction process can produce such a pattern, which can be more easily ascribed to an upward transport of matter and energy sensu lato (Scalera, 2005b).

Then, a WBZs reinterpretation and an orogenic model that could be in harmony with an upward transport of mass have been sought. The high velocity anomalies revealed by means 
of seismic tomographies - regional and global - under the trench-arc zones and orogens (Van der Voo et al., 1999; Fukao et al., 2001; Piromallo and Morelli, 2003; Spakman and Wortel, 2004; Cimini and Marchetti, 2006; among others) can be reinterpreted as isostatically uplifted columns of denser mantle material that intrude between two decoupling plates. The uplifting columns experience episodic phase changes toward open-packed crystal structures that lead to intermediate and deep earthquakes. The cause of the outpouring of materials that are involved in orogenesis should be sought in the increasing volume of the isostatically upwelling material and the contributing buoyancy at the downward displaced Clapeyron phase boundary (Figs. 6 and 7). The higher trench and backarc heat flow can be explained without additional assumptions as a direct consequence of the tensional stress state and of the surfaceward transport of the isotherms that is associated with the columns of uplifting mantle material. It is noteworthy that the new interpretation contains a simple and natural cooperation of deep natural phenomena capable of explaining the surface characteristics of the trench-arc-backarc zones.

In addition, a unified view can be obtained of marine orogenesis - namely the middle oceanic ridges - and continental ones. Indeed, the prolongation of mid-oceanic ridges into dryland fold belts (California, Tonga Kermadek New Zealand) has long been considered a disappointing phenomenon because of the different state of the stress (distensive versus compressive) that was assumed to give rise to them. In this framework the suggestion that the difference between mid-oceanic ridges (marine orogens) and continental fold belts is maintained by different rates of rifting is proposed - mid-oceanic ridges having higher rifting rates which does not allow the growing volume to reach and exceed sea level.

The model can be considered a causal explanation - linked to deep mineralogical phases, isostasy and expanding Earth - of at least a part of an already existing general class of orogenetic non-collisional models (Ollier and Pain, 2000; Ollier, 2003) that derive their evidence above all from surface geology and morphology. Older conceptions appeal to diapirical rises (Carey, 1976, 1986; Van Bemmelen, 1966, 1978) or to uplift of buoyant asthenolithes (Krebs, 1975), but are at odds with the recent seismic tomographic images.

Because of its unique occurrence of a correlation between the major earthquakes and increased eruption rates, South America should be considered a high priority target-region for investigation, since this special continent is also special as far as the unexpected occurrence of the maximum rate of strong deep earthquakes is concerned (depth $\geq 300 \mathrm{~km}$; Frohlich, 2006). The author of this paper considers that this special status of the Nazca-South American region can be a consequence of an asymmetrical global expansion of the planet (Scalera, 2002, 2003, 2006a), with the maximum expansion rate at the Nazca triple point region. Obviously we need a greater amount of data and more time for good observations before being able to provide more definite answers. However, the scientific community should be ready to take the opportunities offered by the extreme and correlated events of this extraordinary continent.

The uniqueness of the region in providing geophysical information and the perspective to increase our knowledge on the real nature of the great shallow earthquakes and on the active margins real geodynamics should be well grounded reason to install permanent OBS and geophysical instruments networks (Husen et al., 2000; Favali and Beranzoli, 2006) along the trenches, like South American Pacific margin, on which extreme magnitude earthquakes and related phenomena are expected to occur (see the recurrence of great seismic events and pulses of eruptions rate in Fig. 2). Continuous satellites observations of ionospheric anomalies as possible precursors of strong earthquakes (Pulinets and Boyarchuk, 2004; Pulinets, 2007; in a vast literature) can also find in South America the region most suitable for investigation, to evaluate the reliability and limits of this new methodology that is similarly ascribed to an emission-activity of the Earth. The scientific benefits possibly acquired - in geosciences, civil protection, but also in other fields - from this eventual endeavour would be of comparable scientific and cultural value with respect to the 'great physics' enterprises, but would be achieved at incomparable lower cost.

Acknowledgements. The ideas herein expressed - which I consider still very imperfect and subject to improvements - are of my personal responsibility. But many people are involved in the progressive clarification of my ideas (or worsening - depending on the reader's point of view). Among them, my thanks go to the colleagues of the Laboratory of Geodynamics of the University "D'Annunzio" of Chieti - and mainly to G. Lavecchia and F. Stoppa, to all my colleagues at INGV working to tomographies and geodynamics, to all the NCGT (New Concepts in Global Tectonics) group, and mainly to Dong Choi. The Italian Geological Society - represented by F.-C. Wezel and F. Calamita - has allowed me to present preliminary versions of these ideas in a Meeting in the Urbino University. C. Ollier with his researches on non collisional mountain building and his continuative e-mail contact has unexpectedly promoted my intention to find a causal solution possibly going ahead with respect to the traditional diapirical solution. P. Fabian has allowed the oral presentation of this contribution to the 2nd Humboldt Conference in Lima, Peru, and suggested along with anonymous referees - invaluable improvements to the manuscript.

Edited by: P. Fabian

Reviewed by: two anonymous referees 


\section{References}

Abrahamson, N., Amin, N., Bardet, J. P., Goltz, J., Lam, I. P., Meyer, J., Moehle, J., O'Rourke, M., Tseng, W. S., and Uzarski, J., EERI Team: The Chi-Chi, Taiwan earthquake of September 21, 1999, EERI Special Earthquake Report, 12 pp., 1999.

Anderson, D. L.: Theory of the Earth (Chapter 16. Phase Changes and Mantle Mineralogy), Boston, Blackwell Scientific Publications, 370 pp., 1989.

Anderson, D. L.: Self-Gravity, Self-Consistency, and SelofOrganization in Geodynamics and Geochemistry, in: Earth's Deep Mantle - Structure, Composition, and Evolution, edited by: Van der Hilst, R. D., Bass, J. D., Matas, J., and Trampert, J., AGU Geophysical Monograph 160, AGU, Washington, 165186, 2005.

Anonymous: The Great Alaska Earthquake, March 27, 1964, State of Alaska Department of Natural Resources, Division of Mines and Minerals, Miscellaneous Paper No. 1, 4 pp., 1964.

Araki, E., Shinohara, M., Obana, K., Yamada, T., Kaneda, Y., Kanazawa, T., and Suyehiro, K.: Aftershock distribution of the 26 December 2004 Sumatra-Andaman earthquake from ocean bottom seismographic observation, Earth Planets Space, 58, 113-119, 2006.

Aubouin, J.: Geosynclines. Elsevier, Amsterdam, 335 pp., 1965.

Babuška, V., Plomerovâ, J., and Šileny, J.: Models of seismic anisotropy in the deep continental lithosphere, Phys. Earth Planet. In., 78, 167-191, 1993.

Barrientos, S. E. and Ward, S. N.: The 1960 Chile earthquake: inversion for slip distribution from surface deformation, Geophys. J. Int., 103, 589-598, 1990.

Bianco, G.: Gli effetti del terremoto del sud-est asiatico sulla geodinamica globale. PowerPoint file of the seminar held at the Meeting Il Terremoto - Maremoto nel Sud-Est Asiatico del 26 dicembre 2004, Accademia Nazionale dei Lincei, Roma January 25, 2005, http://www.fis.uniroma3.it/ plastino/seminars/ terr_mar.html, 2005.

Boschi, E., Guidoboni, E., Ferrari, G., Mariotti, D., Valensise, G., and Gasperini, P.: Catalogue of strong Italian earthquakes from 461 B.C. to 1997 - Introductory texts and CD-rom, Version 3 of: Catalogo dei forti terremoti in Italia, Istituto Nazionale di Geofisica \& Storia Geofisica Ambiente, Bologna, Annali di Geofisica, 43 (4), 607-868 (http://storing.ingv.it/cft/), 2000.

Carey, S. W.: The expanding Earth, Elsevier, Amsterdam, 488 pp., 1976.

Carey, S. W.: Diapiric Krikogenesis, in: The Origin of Arcs, edited by: Wezel, F.-C., Book of invited papers presented at the International Conference "The origin of arcs", held at the University of Urbino, Urbino, Italy, September 22-25 1986, Developments in Geotectonics 21, Elsevier, Amsterdam, Netherlands, 1-40, 1986.

Casertano, L.: General characteristics of active Andean volcanoes and a summary of their activities during recent centuries, B. Seismol. Soc. Am., 53(6), 1415-1433, 1963.

Cattin, R., Loevenbruck, A., and Le Pichon, X.: Why does the coseismic slip of the 1999 Chi-Chi (Taiwan) earthquake increase progressively northwestward on the plane of rupture?, Tectonophysics, 386, 67-80, 2004.

Chopin, C.: Ultrahigh-pressure metamorphism: tracing continental crust into the mantle, Earth Planet. Sc. Lett., 212, 1-14, 2003.

Cifuentes, I. L.: The 1960 Chilean earthquake, J. Geophys. Res., 94(B1), 665-680, 1989.
Cifuentes, I. L. and Silver, P. G.: Low-frequency source characteristics of the great 1960 Chilean earthquake, J. Geophys. Res., 94(B1), 643-663, 1989.

Cimini, G. B. and Marchetti, A.: Deep structure of peninsular Italy from seismic tomography and subcrustal seismicity, in: Frontiers in Earth Sciences: New Ideas and Interpretations, edited by: Lavecchia, G. and Scalera, G., Ann. Geophys.-Italy, Supplement to Vol., 49(1), 331-345, 2006.

Coltorti, M. and Ollier, C. D.: Geomorphic and tectonic evolution of the Ecuadorian Andes, Geomorphology, 32, 1-19, 2000.

Crampin, S.: Calculable fluid-rock interaction, J. Geol. Soc., London, 156, 501-514, 1999.

Cucci, L.: Raised marine terraces in the Northern Calabrian Arc (Southern Italy): a $\sim 600$ kyr-long geological record of regional uplift, Ann. Geophys.-Italy, 47(4), 1391-1406, 2004.

Cucci, L. and Tertulliani, A.: I terrazzi marini nell'area di Capo Vaticano (arco calabro): solo un record di sollevamento regionale o anche di deformazione cosismica? (Marine terraces in the area of Capo Vaticano (Calabrian arc): Only records of regional uplift or also a clue of coseismic deformation?) (in Italian), Il Quaternario - Italian Journal of Quaternary Sciences, 19(1), 89-101, 2006.

Darwin, C.: On the connexion of certain volcanic phenomena in South America; and on the formation of mountains chains and volcanos, as the effect of the same power by which continents are elevated, Transaction of the Geological Society of London, 2d ser., pt. 3(5), 601-631 (reprinted in: The collected papers of Charles Darwin, edited by: Barrett, P. H., The University of Chicago Press, Chicago, 1977, 326 pp.), 1840.

Darwin, C.: Geological observations - on the volcanic islands and parts of south America visited during the voyage of H.M.S. 'Beagle', Third edition, Appleton and Co., New York, 603 pp., 1897.

D'Avity, P.: Le Monde ou la description generale de ses quatre parties. Avec tous ses empires, royaumes, estats, et republiques, où sont deduits \& traictez par ordre leurs noms, assiette, confins, moers, richesses, forces, gouvernement $\&$ religion; et la genealogie des empereurs, roys, \& princes souverains, lesquels y ont dominé iusques à nostre temps. Claude Sonnius \& Denys Bechet, Paris, Tome I, 358 pp., 1643.

Doglioni, C., Mongelli, F., and Pieri, P.: The Puglia uplift (SE Italy): An anomaly in the foreland of the Apenninic subduction due to buckling of a thick continental lithosphere, Tectonics, 13(5), 1309-1321, 1994.

Engdahl, E. R., Van der Hilst, R. D., and Buland, R. P.: Global teleseismic earthquake relocation with improved travel times and procedures for depth determination, B. Seismol. Soc. Am., 88, 722-743, 1998.

Ernst, W. G.: Continental Collision, Mountain Building, and Diamonds in the Rough, P. Am. Philos. Soc., 144(1), 1-32, 2000.

Ernst, W. G.: Subduction, ultrahigh-pressure metamorphism, and regurgitation of buoyant crustal slices - implications for arcs and continental growth, Phys. Earth Planet. In., 127, 253-275, 2001.

Ernst, W. G.: Alpine and Pacific styles of Phanerozoic mountain building: subduction-zone petrogenesis of continental crust, Terra Nova, 17, 165-188, 2005.

Favali, P. and Beranzoli, L.: Seafloor Observatory Science: a review, Ann. Geophys.-Italy, 49(2/3), 515-567, 2006.

Frohlich, C.: Deep Earthquakes, Cambridge University Press, 588 pp., 2006.

Fukao, Y., Widiyantoro, S., and Obayashi, M.: Stagnant slabs in the 
upper and lower mantle transition region, Rev. Geophys., 39(3), 291-323, 2001.

Galli, P. and Bosi, V.: Catastrophic 1638 earthquakes in Calabria (southern Italy): New insights from paleoseismological investigation, J. Geophys. Res., 108(B1), doi:10.1029/2001JB001713.1, 1-20, 2004.

Gambis, D.: Did the Earth's axis tremble? Le Magazine de l'Observatoire de Paris, 1, 13-13, http://www.obspm.fr/ $\sim$ unicom/magazine/IMG/pdf/MagNo1.pdf, 2005.

Gasperini, D., Blichert-Toft, J., Bosch, D., Del Moro, A., Macera, P., Télouk, P., and Albarede, F.: Evidence from Sardinian basalts geochemistry for recycling of plume heads into the Earths mantle, Nature, 408, 701-704, 2000.

Green, D. and Ringwood, A. (Eds.): Phase transformation and the Earth's interior. Proceedings of the Symposium held in Canberra, 6-10 January 1969, by the International Upper Mantle Committee and The Australian Academy of Sciences, North-Holland Publishing Company, Amsterdam, 519 pp., 1970.

Hafkenscheid, E., Buitler, S. J. H., Wortel, M. J. R., Spakman, W., and Bijwaard, H.: Modelling the seismic velocity structure beneath Indonesia: a comparison with tomography, Tectonophysics, 333, 35-46, 2001.

Hanan, B. B.: Mantle recycled in Sardinia, Nature, 408, 657-658, 2000.

Hilgenberg, O. C.: Geotektonik, neuartig gesehen (Geotectonics, seen in a new way), Geotektonische Forschungen, 45(1-2), 194 pp., 1974.

Husen, S., Kissling, E., and Flüh, E. R.: Local earthquake tomography of shallow subduction in north Chile: A combined onshore and offshore study, J. Geophys. Res., 105(B12), 28 183-28 198, 2000.

INGV: Catalogue of Strong Earthquakes in Italy, http://storing.ingv. it/cft/, 2006.

Johnson, K. M. and Segall, P.: Imaging the ramp-décollement geometry of the Chelungpu fault using coseismic GPS displacements from the 1999 Chi-Chi, Taiwan earthquake. Tectonophysics, 378, 123-139, 2004.

Kanamori, H. and Cipar, J. J.: Focal processes of the great Chilean earthquake May 22, 1960. Phys. Earth Planet. In., 9, 128-136, 1974.

Kao, H. and Chen, W.-P.: The Chi-Chi earthquake sequence: Active, out-of-sequence thrust faulting in Taiwan. Science, 288, 2346-2349, 2000.

Kuhn, T.: The Structure of Scientific Revolutions. Chicago University Press, Chicago, 276 pp., 1969.

Krebs, W.: Formation of southwest Pacific island arc-trench and mountain systems: plate or global vertical tectonics. AAPGBull., 59, 1639-1666, 1975.

Lambert, S. B., Bizouard, C., and Dehant, V.: Rapid variations in polar motion during the 2005-2006 winter season. Geophys. Res. Lett., 33, L13303, doi:10.1029/2006GL026422, 1-4, 2006.

Landen, D.: Alaska earthquake, 27 March 1964. Science. 145, 7476, 1964.

Lawrence, J. F. and Wysession, M. E.: Seismic Evidence for Subduction-Transported Water in the Lower Mantle, in: Earth's Deep Water Cycle, American Geophysical Union Geophysical Monograph Series 168, 251-261, 2006.

Linde, A. T. and Silver, P. G.: Elevation changes and the great 1960 Chilean earthquake: Support for aseismic slip, Geophys. Res.
Lett., 16(11), 1305-1308, 1989.

Lund, F.: Interpretation of the precursor to the 1960 great Chilean earthquake as a seismic solitary wave. Preprint of the Depart, De Fisica, Faculdad de Ciencias Fisicas y Matematicas Universidad de Chile, 23 pp., 1982.

Mac Millan, D.: Could we have detected the Sumatra Earthquake with VLBI? IVS Newsletter, April 2005(11), 1-1, 2005.

Mainprice, D., Barruol, G., and Ismail, W. B.: The seismic anisotropy of the Earth's mantle: From single crystal to polycrystal, in: Earth's Deep Interior: Mineral Physics and Tomography From the Atomic to the Global Scale, edited by: Karato, S., Forte, A., Liebermann, R., Masters, G., and Stixrude, L., AGU Geophys. Monogr. Ser., 117, 237-264, 2000.

Mancktelow, N.: Nonlithostatic pressure during sediment subduction and the development and exhumation of high pressure metamorphic rocks, J. Geophys. Res., 100(B1), 571-583, 1995.

Mancktelow, N.: Exhumation of high-pressure rocks, in: CrustMantle Interactions, edited by: Ranalli, G., Ricci, C. A.,and Trommsdorff, V., Proceedings of the International School Earth and Planetary Sciences, Siena, 41-52, 2000.

Margheriti, L., Lucente, F. P., and Pondrelli, S.: SKS splitting measurements in the Apenninic-Tyrrhenian domain (Italy) and their relation with lithospheric subduction and mantle convection, J. Geophys. Res., 108(B4), 2218, doi:10.1029/2002JB001793, 2003.

McElhinny, M. W. and McFadden, P. L.: Paleomagnetism, continents and oceans, Academic Press, New York, 380 pp., 2000.

Mishra, O. P., Kayal, J. R., Chakrabortty, G. K., Singh, O. P., and Ghosh, D.: Aftershock investigation in the Andaman-Nicobar Islands of India and its seismotectonic implications, B. Seismol. Soc. Am., 97(1A), S71-S85, 2007.

Moretti, A. and Guerra, I.: Tettonica dal Messiniano ad oggi in Calabria: Implicazioni sulla geodinamica del sistema TirrenoArco Calabro, Boll. Soc. Geol. It., 116, 125-142, 1997.

Mouritsen, S. A.: Introduction to the genesis of planetary structure and Terrestrial maria, Geol. Rundsch., 64, 899-915, 1975.

Müller, R. D.: An Indian cheetah, Nature, 449, 795-797, 2007.

Müller, R. D., Roest, W. R., Royer, J. Y., Gahagan, L. M., and Sclater, J. G.: Digital isochrons of the world's ocean floor, J. Geophys. Res., 102, 3211-3214, 1997.

Newhall, C. G. and Self, S.: The volcanic explosivity index (VEI): an estimate of explosive magnitude for historical volcanism, J Geophys. Res. (Oceans \& Atmospheres), 87, 1231-1238, 1982.

Ollier, C. D.: The structure and origin of mountains: pre-planation and post-planation gravity structures, in: Large Scale vertical movements and related gravitational processes, edited by: Dramis, F., Proceedings of the International Workshop held in Camerino and Rome 21-26 June 1999, Camerino University Publication (special number), 147-155, 2002.

Ollier, C. D.: The origin of mountains on an expanding Earth, and other hypotheses, in: Why Expanding Earth? - A book in Honour of Ott Christoph Hilgenberg, edited by: Scalera, G. and Jacob, K.-H., Proceedings of the 3rd Lautenthaler Montanistisches Colloquium, Mining Industry Museum, Lautenthal (Germany) May 26, 2001, INGV, Rome, 129-160, 2003.

Ollier, C. D. and Pain, C.: The origin of mountains, Routledge, London and New York, 345 pp., 2000.

Perin, I.: Expansão em anel hemisférico terrestre, Bol. Res. Expand. Soc. Bras. Geol., 2, 267-267, 1994. 
Perin, I.: The expanding hemispheric ring, in: Why Expanding Earth? - A book in Honour of Ott Christoph Hilgenberg, edited by: Scalera, G. and Jacob, K.-H., Proceedings of the 3rd Lautenthaler Montanistisches Colloquium, Mining Industry Museum, Lautenthal (Germany) May 26, 2001, INGV, Rome, 243-257, 2003.

Piromallo, C. and Morelli, A.: P-wave tomography of the mantle under the Alpine-Mediterranean area, J. Geophys. Res., 108(B2), 2065, doi:10.1029/2002JB 001757, 2003.

Pitcher, W. S.: The nature and origin of granite, Blackie Academic \& Professional, Glasgow, 321 pp., 1993.

Placet, F.: La corruption du grand et petit monde. Où il est traité des changemens funestes arrivez en tout l'univers e en la nature humaine depuis le peché d'Adam, Alliot \& Alliot, Paris, 367 pp., 1666.

Plafker, G.: Tectonic deformation associated with the 1964 Alaska earthquake, Science, 148(3678), 1675-1687, 1965.

Plafker, G. and Savage, J. C.: Mechanism of the Cilean Earthquakes of May 21 and 22, 1960, Geol. Soc. Am. Bull., 81, 1001-1030, 1970.

Platt, J. P.: Dynamics of orogenic wedges and the uplift of highpressure metamorphic rocks, Geol. Soc. Am. Bull., 97, 10371053, 1986.

Polino, R., Dal Piaz, G. V., and Gosso, G.: Tectonic erosion at the Adria margin and accretionary processes for the Cretaceous orogeny of the Alps, Mem. Soc. Geol. France, 156, 345-367, 1990.

Press, F. and Jackson, D.: Alaskan earthquake, 27 March 1964: Vertical extent of faulting and elastic strain energy release, Science, 147, 867-868, 1964.

Pulinets, S. A.: Natural radioactivity, earthquakes, and ionosphere, EOS Transactions AGU, 88(20), 217-224, 2007.

Pulinets, S. A. and Boyarchuk, K. A.: Ionospheric precursors of earthquakes, Springer, New York, 315 pp., 2004.

Puspito, N. T. and Shimazaki, K.: Mantle structure and seismotectonics of the Sunda and Banda Arcs, Tectonophysics, 251, 215228, 1995.

Ranalli, G.: Rheology of the Earth, Chapman \& Hall, London, 436 pp., 1995.

Read, H. H.: The granite controversy, T. Murby \& Co., London, 430 pp., 1957.

Ren, Y., Stutzmann, E., Van der Hilst, R. D., and Besse, J.: Understanding seismic heterogeneities in the lower mantle beneath the Americas from seismic tomography and plate tectonic history, J. Geophys. Res., 112, B01302, doi:10.1029/2005JB004154, 2007.

Ritsema, A. R.: The mechanism of mantle earthquakes in relation to phase transformation processes, in: 1970: Phase Transformation and the Earth's Interior, edited by: Green, D. and Ringwood, A., Proceedings of the symposium held in Canberra, 6-10 January 1969 , by the International Upper Mantle Committee and the Australian Academy of Sciences, North-Holland Publishing Company, Amsterdam, 503-510, 1970.

Rohrbach, A., Ballhaus, C., Golla-Schindler, U., Ulmer, P., Kamenetsky, V. S., and Kuzmin, D. V.: Metal saturation in the upper mantle., Nature, 449, 456-458, 2007.

Saroli, M., Stramondo, S., Moro, M., and Doumaz, F.: Movements detection of deep seated gravitational slope deformations by means of InSAR data and photogeological interpretation: northern Sicily case study, Terra Nova, 17, 35-43, 2005.
Savage, J. C. and Hastie, L. M.: Surface deformation associated with dip-slip faulting, J. Geophys. Res., 71(20), 4897-4904, 1966.

Scalera, G.: The relation among seismic activity, volcanic rock emplacement and Bouguer anomalies in Italy, Nat. Hazards, 15, 165-181, 1997.

Scalera, G.: Possible relations among expanding Earth, TPW and Polar Motion, in: Proceedings International Symposium on New Concepts in Global Tectonics, edited by: Maslov, L., held in May 2002 in La Junta, Colorado, Otero Junior College Press, La Junta, 37-50, 2002.

Scalera, G.: The expanding Earth: a sound idea for the new millennium, in: Why Expanding Earth? - A book in Honour of Ott Christoph Hilgenberg, edited by: Scalera, G. and Jacob, K.H., Proceedings of the 3rd Lautenthaler Montanistisches Colloquium, Mining Industry Museum, Lautenthal (Germany) May 26, 2001, INGV, Rome, 181-232, 2003.

Scalera, G.: The geodynamic meaning of the great sumatran earthquake: inferences from short time windows, New Concepts in Global Tectonics Newsletter, no. 35 (June), 8-23, 2005a.

Scalera, G.: A new interpretation of the Mediterranean arcs: Mantle wedge intrusion instead of subduction, Boll. Soc. Geol. It., Volume Speciale no. 5, 129-147, 2005b.

Scalera, G.: TPW and Polar Motion as due to an asymmetrical Earth expansion, in: Frontiers in Earth Sciences: New Ideas and Interpretations, edited by: Lavecchia, G. and Scalera, G., Annals of Geophysics, Supplement to Vol. 49(1), 483-500, 2006a.

Scalera, G.: The geodynamic meaning of the Wadati-Benioff earthquakes: From Apennines to a global perspective for mountainbuilding, in: Extended abstracts book of the 25th GNGTS (National Group for Solid Earth Geophysics), edited by: Slejko, D. and Rebez, A., Annual Meeting, Rome, 28-30 November 2006, 8-14, 2006b.

Scalera, G.: The geodynamic meaning of the deep earthquakes: First clues for a global perspective for fold belts?, New Concepts in Global Tectonics Newsletter, no. 41 (December), 45-54, 2006 c.

Scalera, G.: Terremoti, trasformazioni di fase, catene a pieghe: è possibile una nuova prospettiva globale? (Earthquakes, phase changes, fold belts: it is possible a new global perspective?) (in Italian), Rendiconti Soc. Geol. It., 4, Nuova Serie, 296-299, 2007a.

Scalera, G.: Geodynamics of Wadati-Benioff zone earthquakes: The 2004 Sumatra earthquake and other great earthquakes, Geofísica Internacional, 46(1), 19-50, 2007b.

Scalera, G. and Jacob, K.-H. (Eds.): Why Expanding Earth? - A book in Honour of Ott Christoph Hilgenberg, Proceedings of the 3rd Lautenthaler Montanistisches Colloquium, Mining Industry Museum, Lautenthal (Germany) May 26, 2001, INGV, Rome, 465 pp., 2003.

Schubert, G., Yuen, D. A., and Turcotte, D. L.: Role of phase transitions in a dynamic mantle, Geophys. J. Int., 42(2), 705-735, 1975.

Searle, M.: Co-seismic uplift of coral reefs along the western Andaman Islands during the December 26th 2004 earthquake, Coral Reefs, 25(1), p. 2, doi:10.1007/s00338-005-0051-z, 2005.

Searle, M., Bradley, R. H., and Bilham, R.: The Hindu Kush Seismic Zone as a Paradigm for the Creation of Ultrahigh-Pressure Diamond- and Coesite-Bearing Continental Rocks, J Geol., 109, 
143-153, 2001.

Seno, T.: Report on the surface ruptures of the Taiwan earthquake on Sept. 20, 1999, http://www.eri.u-tokyo.ac.jp/seno/Taiwan. report.eng.html, 2000.

Seno, T., Otsuki, K., and Yang, C.-N.: The 1999 Chi-Chi, Taiwan earthquake: A subduction zone earthquake on land, Bull. Earthquake Res. Inst., 75, 57-77, 2000.

Serpelloni, E., Anzidei, M., Baldi, P., Casula, G., and Galvani, A.: GPS measurement of active strains across the Apennines, in: Frontiers in Earth Sciences: New Ideas and Interpretations, edited by: Lavecchia, G. and Scalera, G., Ann. Geophys.-Italy, Supplement to Vol. 49(1), 483-500, 2006.

Shin-Chan Han, Shum, C. K., Bevis, M., Chen Ji, and ChungYen Kuo: Crustal dilatation observed by GRACE after the 2004 Sumatra-Andaman earthquake, Science, 313, 4 August, 658662, 2006.

Shin, T. C., Kuo, K. W., Lee, W. H. K., Teng, T. L., and Tsai, Y. B.: A preliminary report on the 1999 Chi-Chi (Taiwan) earthquake, Preprint, 16 pp., 1999.

Simkin, T. and Siebert, L.: Volcanoes of the World (2nd edition), Geoscience Press in association with the Smithsonian Institution Global Volcanism Program, Tucson AZ, 368 pp., 1994.

Smithsonian Institution: Global Volcanism Program, Facilities on the web-site: http://www.volcano.si.edu, 2006.

Spakman, W. and Wortel, R.: A tomographic view on Western Mediterranean geodynamics, in: The Transmed Atlas - The Mediterranan Region from Crust to Mantle, edited by: Cavazza, W., Roure, F. M., Spakman, W., Stampfli, G. M., and Ziegler, P. A., Springer, Berlin, 32-52, 2004.

Subbotin, S. I.: Phase transformations within the Earth's mantle as a cause of crustal movement and a source of crustal material, in: 1970: Phase Transformation and the Earth's Interior, edited by: Green, D. and Ringwood, A., Proceedings of the symposium held in Canberra, 6-10 January 1969, by the International Upper Mantle Committee and the Australian Academy of Sciences, North-Holland Publishing Company, Amsterdam, 499502,1970
Stauder, W. and Bollinger, G. A.: The focal mechanism of the Alaska earthquake of March 28, 1964, and its aftershock Sequence, J. Geophys. Res., 71(22), 5283-5296, 1966.

Stöckhert, B.: Eclogite and stress, Mitt. Österr. Miner. Ges., 150, 2005.

Stöckhert, B. and Gerya, T. V.: Pre-collisional high pressure metamorphism and nappe tectonics at active continental margins: a numerical simulation, Terra Nova, 17, 102-110, 2005.

Stöcklin, J.: Abrief report on geodynamics in Iran, in: Zagros, Hindu Kush, Himalaya geodynamic evolution, edited by: Gupta H. K. and Delany, F. M., AGU Geodyn. Ser., 3, 70-74, 1981.

Stöcklin, J.: Tethys evolution in the Afghanistan-Pamir-Pakistan region, in: Tectonic Evolution of the Tethyan Region, edited by: Sengör, A. M. C., Kluver Academic Publishers, 241-264, 1989.

Tiberti, M. M., Fracassi, U., and Valensise, G.: Il quadro sismotettonico del grande terremoto del 1905, in: 8 settembre $1905-$ Terremoto in Calabria, edited by: Guerra, I. and Savaglio, A., Pubblicazione del Dipartimento di Fisica dell'Università della Calabria, Castrovillari, 181-205, 2006.

USGS: Earthquake Hazards Program - Online Earthquakes Global and regional Catalogues Search, http://neic.usgs.gov/neis/epic/ epic.html, 2007.

Valensise, G. and Pantosti, D.: A 125 Kyr-long geological record of seismic source repeatability: the Messina Straits (southern Italy) and the 1908 earthquake (Ms 7 $\frac{1}{2}$ ), Terra Nova, 4, 472-483, 1992.

Van Bemmelen, R. W.: On Mega-Undations: A new model for the Earth's evolution, Tectonophysics, 3(2), 83-127, 1966.

Van Bemmelen, R. W.: The present formulation of the Undation Theory, in: The Frontiers of Human Knowledge, Acta Universitatis Upsaliensis, 255-274, 1978.

Van der Hilst, R. D., Bass, J. D., Matas, J., and Trampert, J. (Eds.): Earth's Deep Mantle: Structure, Composition, and Evolution, AGU Geophysical Monograph 160, Washington, 334 pp., 2005.

Van der Voo, R., Spakman, W., and Bijwaard, H.: Tethyan subducted slabs under India, Earth Planet. Sc. Lett., 171, 7-20, 1999. 